\title{
Perception Analysis of Consumers towards the usage of Sustainable Organic Food Products in Indian Subcontinent
}

\author{
Ratna Banerjee \\ School of Business, University of \\ Petroleum \& Energy Studies \\ Dehradun, India
}

\author{
Remica Aggarwal \\ School of Business, University of \\ Petroleum \& Energy Studies \\ Dehradun, India
}

\author{
Veena Aggarwal \\ Recventures Education Services \\ Private Limited \\ Delhi, India
}

\begin{abstract}
Present study tries to explore and analyse interesting aspects related to consumer behaviour, perceptions and attitudes about organic food products in Indian sub-continent . It also relates such consumption patterns with the consumers' understanding and points of view towards organic food as well as their demographic, socio-economic, purchasing patterns and consumption patterns profiles. Based on the conceptual framework which identify the required criteria that influences the consumer perceptions and attitude towards organic food products, data is collected from randomly selected organic food consumers through online as well as offline survey and using semi-structured questionnaire. A detailed data analysis using exploratory factor analysis is then performed using the SPSS software and results are presented.
\end{abstract}

\section{Keywords}

Organic food products, sustainability, purchasing patterns, consumption patterns

\{Note : This paper is an extended version of the paper titled Aggarwal, R. and Banerjee, R."A Conceptual Framework to measure customer experience towards organic food products in India" ( with Banerjee, R. ), presented at ICSMS , IMT Nagpur, 2018 \}

\section{INTRODUCTION}

Environment sustainability is a growing concern today . Not only the today's era consumers but also the organizations are getting aware of the benefits of the sustainable food products such as organic food as an alternative to look for healthier options for food products . Credit obviously goes to the increasing education level as well as income level of the consumer which is making them more aware about the healthier options for food so that they can survive under the stress and competition of today. It goes by saying " Eat healthy, Stay healthy". In third world countries such as India, benefits of organic food products have been realized gradually and government is also launching new policies and reforms so as to motivate and train the farmers in sustainable farming practices and in the safe use of its products. Policy changes or new policy with regard to sustainable product sector will boost the economy of the country. Policies for new product development will not only enhance the upcoming sustainable products' entire supply chain but also increase the country's revenue simultaneously being environment conscious.

As consumers are becoming more health conscious, it is of curiosity to analyze the motivators behind the purchase of these sustainable or organic food products. Thus, the primary objectives of the present study are as follows:
- Identifying the level of awareness amongst consumers with respect to organic food products

- Studying the impact of education on the consumption pattern for organic food products

- Studying the buying behaviour and attitudes of consumers towards organic food products and identifying the success factor for sustainability of organic food product.

- Studying the correlation between the socioeconomic factors and the beliefs and perception of consumers

The paper is arranged as follows: Section 2 deals with the literature review. Section 3 describes the case problem and the methodologies. Section 4 deals with conceptual framework and development of hypotheses. Section 5 presents the data analysis through factor analysis. Section 6 presents the managerial implications and extensions whereas section 7 presents concluding remarks.

\section{LITERATURE REVIEW}

This section presents the review of literature in two subsections . First section reviews the literature to identify various influencing factors building consumer perceptions towards organic food products whereas section 2.2 discusses various methodologies used over years to study and measure the effect of various factors on the consumer purchase of organic food products.

\subsection{Literature review of the underlying criteria / constructs}

Table 1 below shows the literature review of research papers underlying various criteria or constructs to determine the consumer perceptions, attitudes, awareness and purchasing behavior of consumers towards organic food products and their year of publication. 
Table 1. Various constructs or criteria for measuring consumer perceptions about organic food products

\begin{tabular}{|c|c|c|}
\hline Constructs / criteria & $\begin{array}{c}\text { Variables taken } \\
\text { under study }\end{array}$ & $\begin{array}{c}\text { Reference } \\
\text { number }\end{array}$ \\
\hline $\begin{array}{l}\text { Consumer attitudes / } \\
\text { motivation } \\
\text { /perceptions / beliefs } \\
\text { to purchase organic } \\
\text { food products }\end{array}$ & $\begin{array}{l}\text { gender, age groups, } \\
\text { education, marital } \\
\text { status, household } \\
\text { size, per capita } \\
\text { income, municipality } \\
\text { size }\end{array}$ & $\begin{array}{c}1],[2],[3], \\
{[4],} \\
{[5],[6],[7],[8} \\
],[9]\end{array}$ \\
\hline $\begin{array}{l}\text { Consumer } \\
\text { willingness to pay for } \\
\text { organic food } \\
\text { products / consumer } \\
\text { intention to buy } \\
\text { organic food } \\
\text { products }\end{array}$ & $\begin{array}{l}\text { purchase intention, } \\
\text { attitude, ethical self- } \\
\text { identity, food safety } \\
\text { concerns, health } \\
\text { consciousness }\end{array}$ & $\begin{array}{l}10],[11], \\
{[12],[13]}\end{array}$ \\
\hline $\begin{array}{l}\text { Consumer awareness } \\
\text { / subjective and } \\
\text { objective knowledge }\end{array}$ & $\begin{array}{c}\text { Awareness, } \\
\text { subjective knowledge } \\
\text {, objective } \\
\text { knowledge }\end{array}$ & $\begin{array}{c}\text { [12], [14], } \\
{[15]}\end{array}$ \\
\hline $\begin{array}{c}\text { Demographic } \\
\text { variables } \\
\text { (age , income } \\
\text { gender ) and food } \\
\text { choices }\end{array}$ & $\begin{array}{c}\text { Food safety, } \\
\text { convenience, } \\
\text { education, age, house } \\
\text { hold size, trust, price, } \\
\text { openness, price }\end{array}$ & $\begin{array}{c}{[16],[17],[18} \\
],[19],[20]\end{array}$ \\
\hline $\begin{array}{l}\text { Pesticide free organic } \\
\text { food products / no } \\
\text { chemical material / } \\
\text { health related } \\
\text { determinants / food } \\
\text { safety / food quality }\end{array}$ & $\begin{array}{l}\text { Motivating factors - } \\
\text { healthy, safety level, } \\
\text { better treatment of } \\
\text { animals, } \\
\text { environment, natural } \\
\text { taste, quality, fashion }\end{array}$ & $\begin{array}{c}{[17],} \\
{[21],[22],[23} \\
]\end{array}$ \\
\hline Organic labelling & $\begin{array}{l}\text { Age, income, number } \\
\text { of adults, number of } \\
\text { children, gender, } \\
\text { education, marriage, } \\
\text { employment }\end{array}$ & [24-26] \\
\hline $\begin{array}{l}\text { Pricing / Purchase } \\
\text { criteria }\end{array}$ & $\begin{array}{c}\text { Monthly income } \\
\text { employment }\end{array}$ & [26] \\
\hline
\end{tabular}

consumers' perception of health, safety, environmental factors and animal welfare of products. Study by [29] focuses on increasing consumer awareness about organic foods among Australia. The sample size chosen for the study is 1011 through online survey based on demographic profile that support for the research hypotheses by revealing positive and significant effects of the healthiest, hedonism and trust on consumer purchase intention.

\section{PROPOSED METHODOLOGY: Factor analysis}

This sections presents in detail the questionnaire which was designed to be circulated amongst the target consumers. This has been presented in section 3.1. Section 3.2 presents the conceptual framework to highlights the various criteria that build up the consumer attitude the purchase of organic food products in India. This serve as the basis for performing the factor analysis.

\subsection{Data collection}

Research is conducted in two stages . In the first stage, a focus group or targeted consumers have been recognized. Initially the research is exploratory in nature. Based on the literature exploration, various factors influencing the consumer's experience are determined and a questionnaire has been designed to collect the responses on various aspects of buying behaviour, consumption patterns, demand and supply gap, economics of consumers. Thereafter the questionnaire is circulated amongst the respondents of age groups 18-60 years who are contacted via online as well as offline survey. The questionnaire consists of closed as well as open ended questions.

\subsection{Questionnaire design}

Questionnaire consists of multiple sections. The first section of the questionnaire includes background questions which includes questions on demographic variables such as age, income, gender, education level, monthly income of family, occupation, family size and number of working persons in the family. Second section of the questionnaire includes the awareness questions. Third section of the questionnaire includes questions to test the customer's beliefs, knowledge, attitude and perceptions of consumers towards organic food products. Fourth section of questionnaire includes questions to test the consumption patterns and fifth section to test the purchasing behaviour of the consumers towards organic food products.

\subsection{Conceptual framework}

A brief snapshot of the conceptual framework have been presented below . Readers may refer to [30] for the detailed

\subsection{Literature review of the similar studies conducted}

Attanasio et al. [27] interviewed 280 respondents using semi structured questionnaires examines the consumer's intention to purchase the organic food products in Pontina Province, Italy . The results indicated that the buying intention about the organic products is influenced by the perception about the value of organic food products and belief in the health and safety of the product. [28] examines about consumer perception, actual purchase behaviour, purchase intentions and interrelationship between them in context of organic food products in the district of Kluang, Johor, Malaysia. The results indicated that purchase of organic food was influenced by 
explanation.

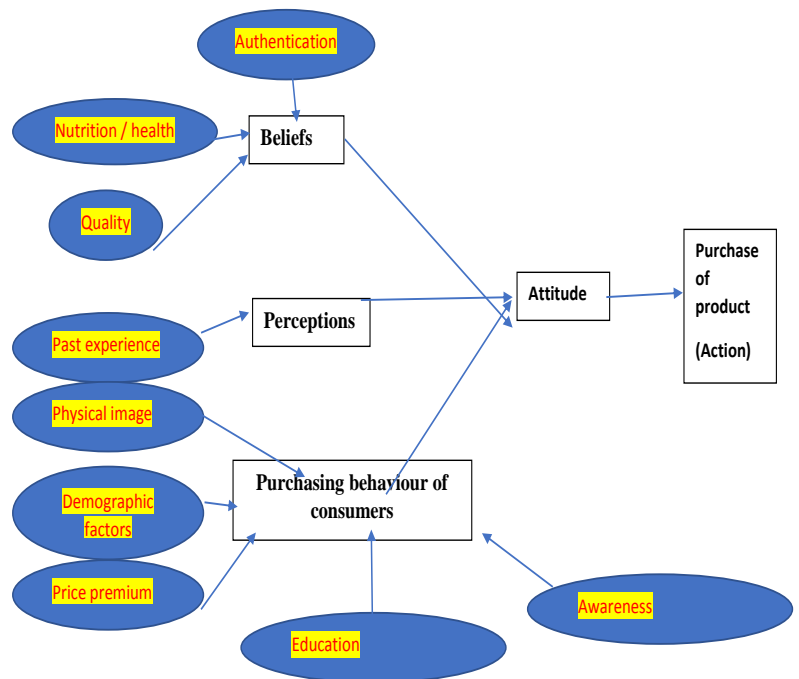

Figure I: Conceptual framework portraying various factors affecting the attitude of the consumer to buy the organic food

product

\section{DEVELOPMENT OF HYPOTHESES}

Various hypotheses are constructed to analyze the impact of belief, perceptions and purchasing behavior on building attitude of consumers towards the purchase of organic food products in India. These hypotheses have been discussed in detail and the literature explaining the concept in [30].

\section{DATA ANALYSIS AND RESULTS}

This section discusses the various stages of data collection, the scales and measures used, results of the analysis of demographic details of the respondents and the analysis of various aspects of consumer behaviour towards the organic food products purchase. The scale to measure these consists of 10 point Likert's scale ( $1=$ least influence / least spent to $10=$ most influence / extremely more spent) in which individuals entertain varying degrees of both satisfaction and dissatisfaction in their judgments. For each question, respondents were asked to mark the response that best described their level of agreement. Overall 50 complete and usable questionnaires were obtained. Some key features of the data analysis performed are as follows:

The collected data from the sample respondents have been analyzed and interpreted with the help of statistical tools like percentage analysis, Reliability test, KMO/Bartlett's test and exploratory factor analysis (at 100\% cumulative variance).

A Likert-type scale was used when respondents were asked to point out their opinions and attitudes.

- Descriptive statistics has been further used to determine percentages, arithmetic means, and standard deviation.

- To perform the analysis software such as SPSS is used .

\subsection{Descriptive statistics and Data visualization of the demographic characteristics of the respondents and their socio-economic data}

5.1.1 Demographic distribution of the respondents
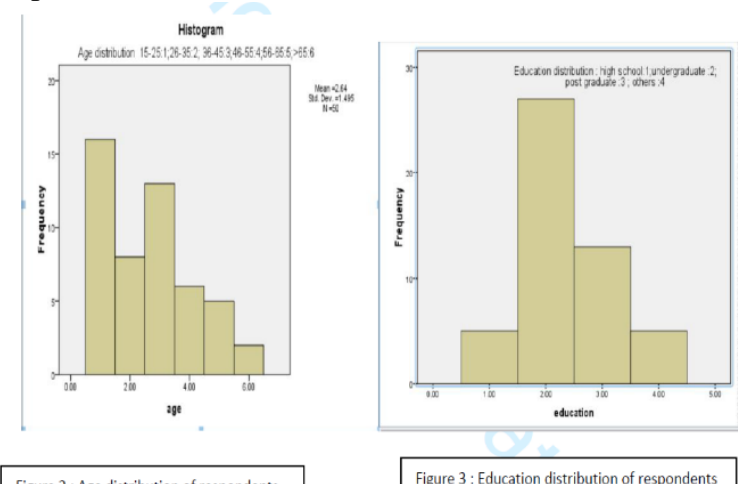

Figure 2: Age distribution of respondents
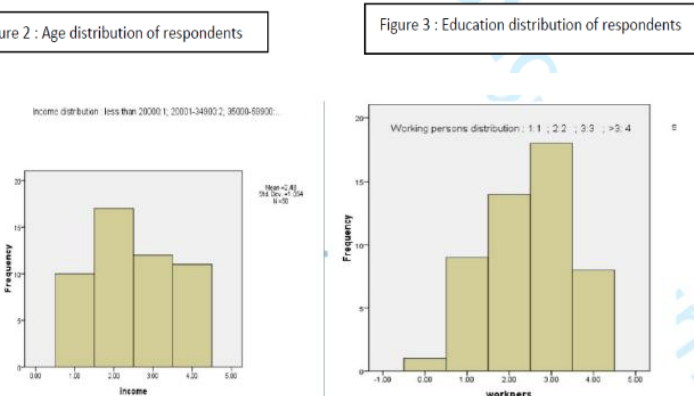

Figure 4 : Income distribution of respondents
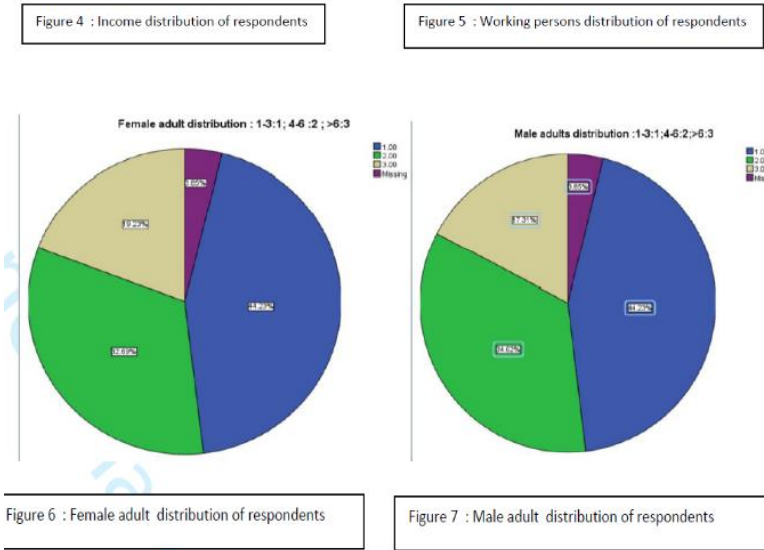

Figure 7 : Male adult distribution of respondents

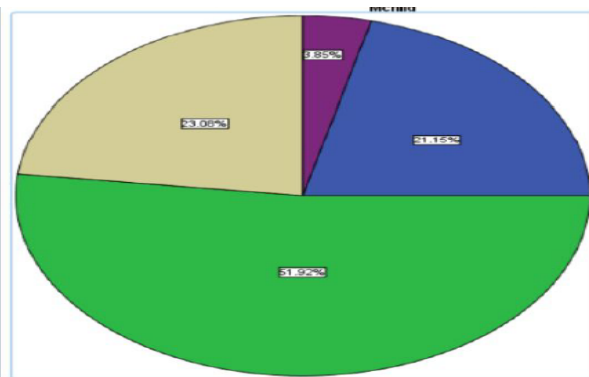

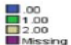

Figure 8 : Male child distribution of respondents 


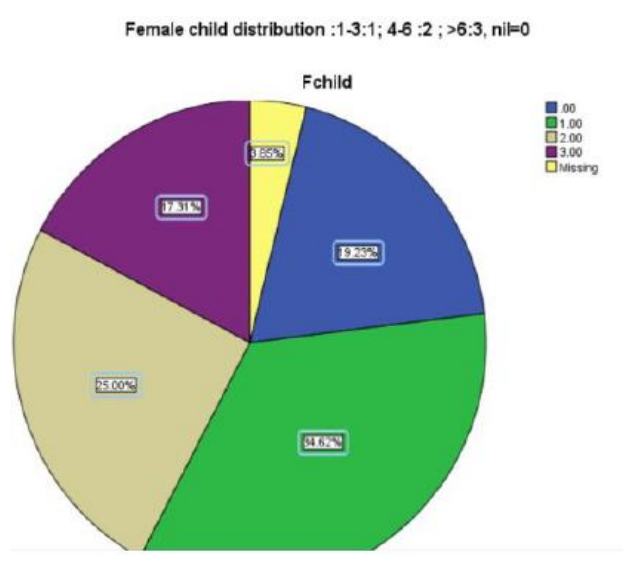

Figure 9 : Female child distribution of respondents

5.1.2 5.1.2 Data analysis of level of awareness about environment and organic food products
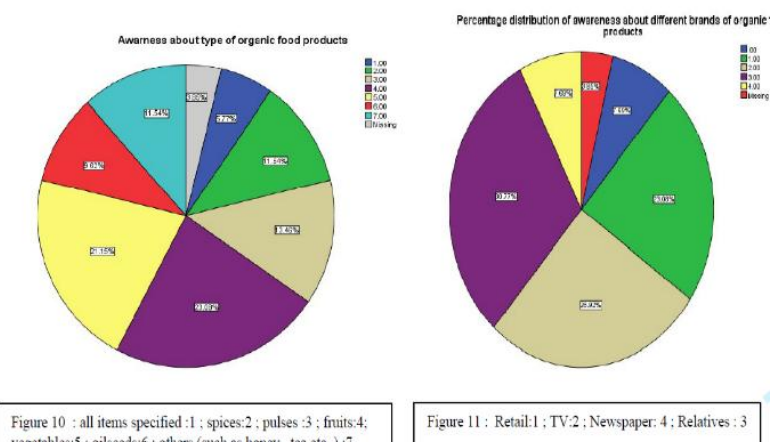

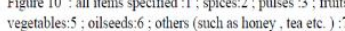

Figure 11 : Retail 1 ; TV: 2 Newspaper. 4 : Relatives : 3
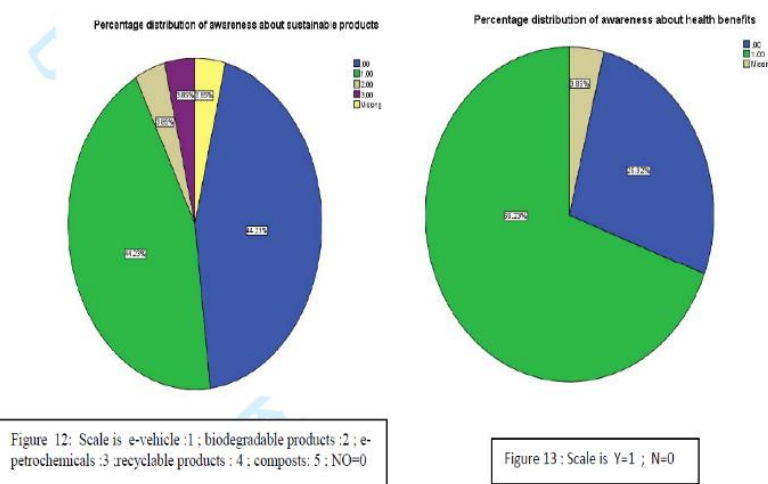

Figure 13 : Scale is $Y=1 ; N=0$

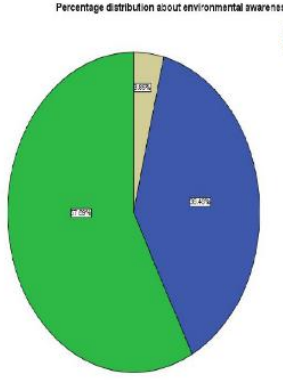

$\mathrm{m}_{\mathrm{m}}$

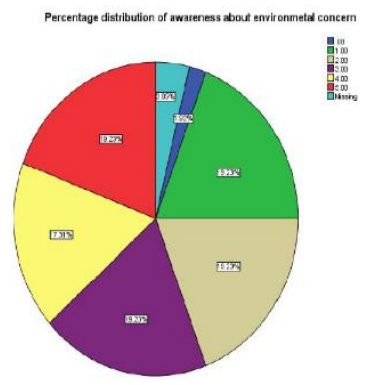

Figure $14: \mathrm{Y}=1 ; \mathrm{N}=0$
5.1.3 Studying the correlation between the socioeconomic factors and the beliefs and perception of consumers

Table 2. below shows the correlation between the socio economic and demographic profile of respondents with beliefs and perception about organic food purchase.

Table 2. Correlation between education, income, occupation, quality trademark, type of quality mark, expiration date and beliefs $\&$ perceptions about organic food

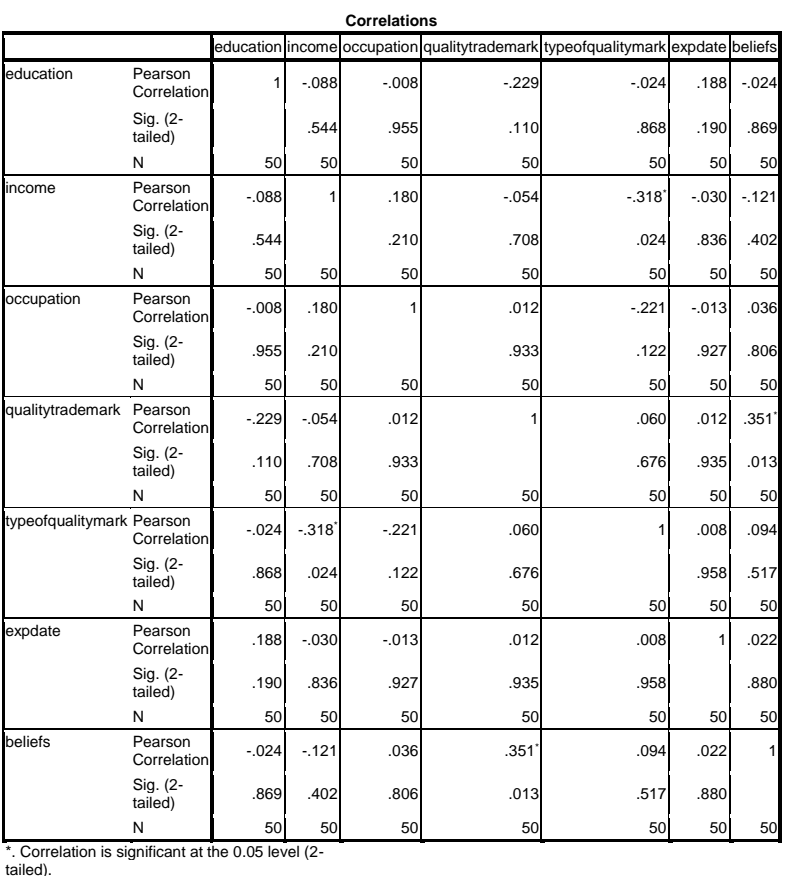

\subsubsection{Analysis of the consumption patterns of the} respondents
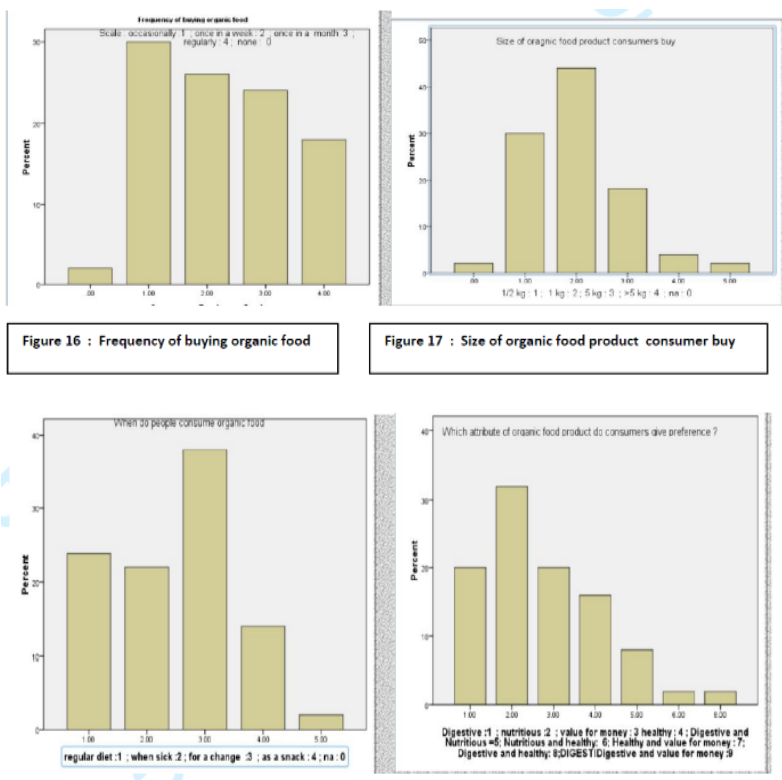

Figure 18 : When do people purchase organic food product
Figure 19: Which attribute of organic food product do consumers give preference 

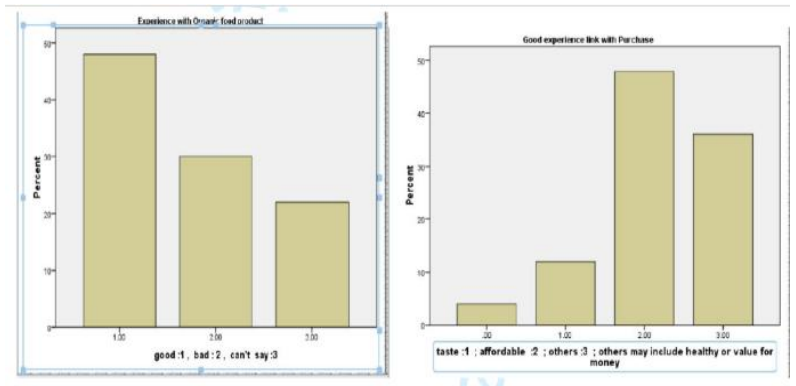

Figure 20 : Experience with organic food product

Figure 21 : Good experience link with Purchase

5.1.5 Analysis of purchase behaviour i.e. monetary distribution of salary on organic foods
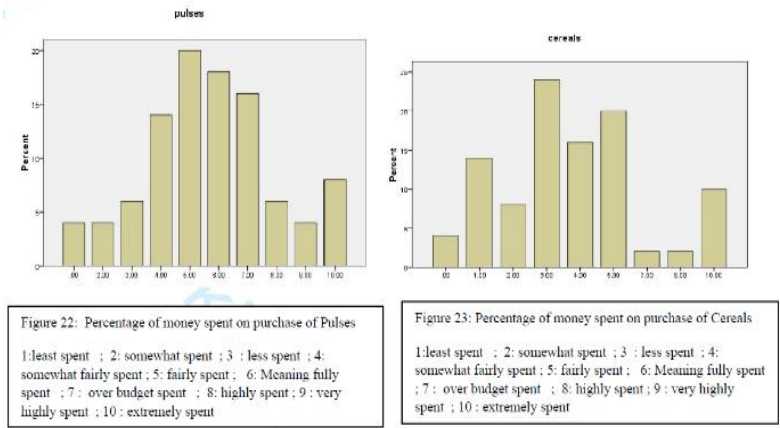

sockentosost

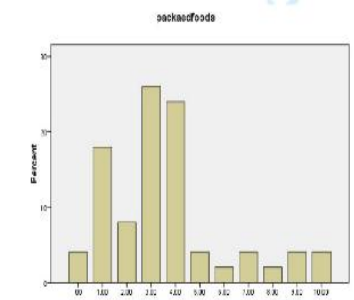

Figure 24: Percentrage of money spent on purcliase of Packaged foods

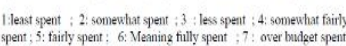

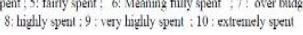
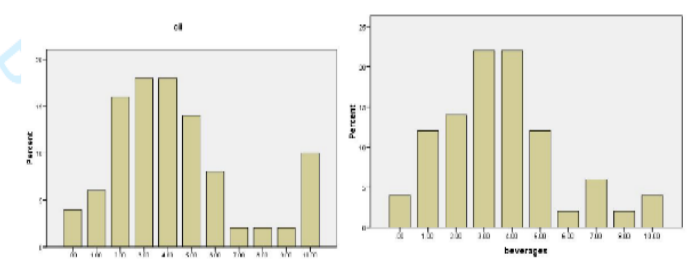

Tiqure 26: Percentage of money spent on purchiss of 0 에

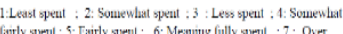

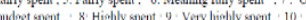
isdeget ppent :

\subsubsection{Factor analysis}

Factors considered for consumer perception towards organic products . Factor analysis is used to analyze and identify the consumer perception towards organic products. The 15 factors identified namely Factor 1 , Factor 2 , ...Factor 15 given in the table below. First, the rotated component matrix factor loadings greater than 0.5 is to be selected. Extraction method used is principle component analysis. Rotation method used is varimax with Kaiser normalization. Factor loadings in rotated component matrix at $100 \%$ cumulative variance .

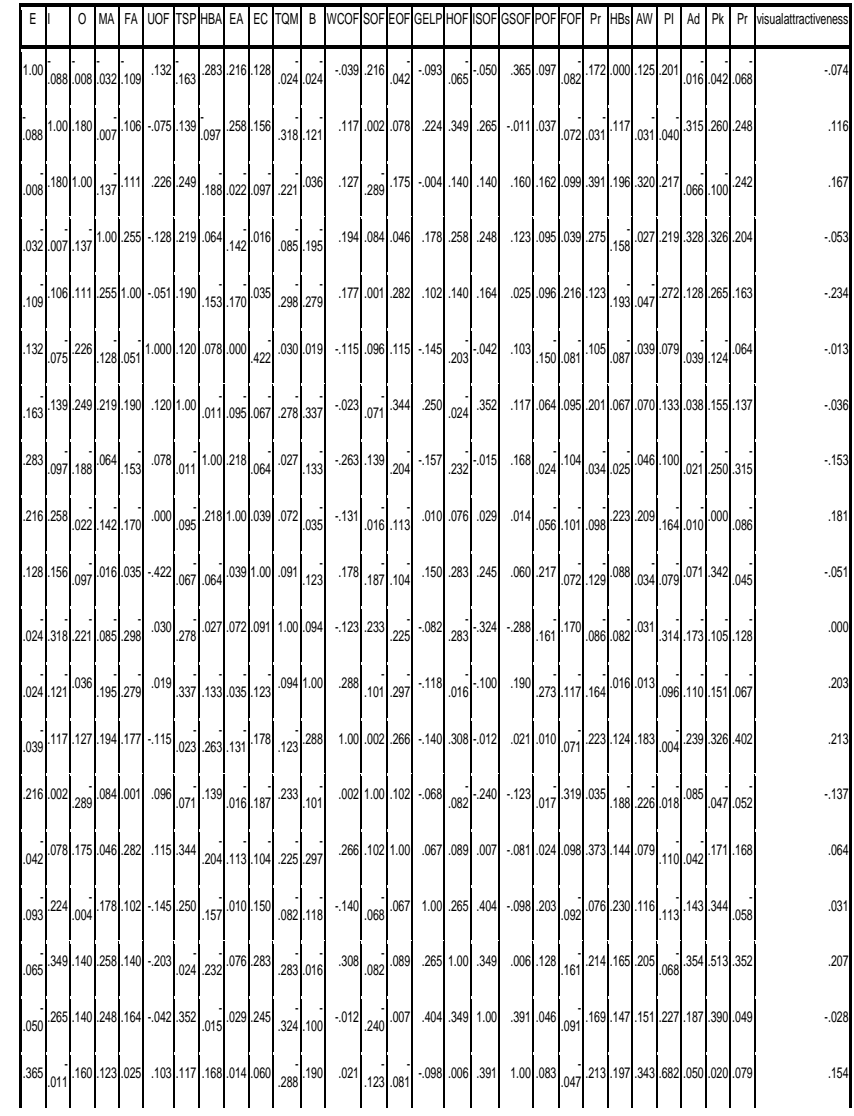

5.1.7 KMO's and Bartlett test

\begin{tabular}{|c|c|c|}
\hline \multicolumn{2}{|c|}{$\begin{array}{c}\text { Kaiser Meyer Olkin measure of sampling } \\
\text { adequacy }\end{array}$} & $0.493(0.5)$ \\
\hline $\begin{array}{c}\text { Bartlett test of } \\
\text { sphericity }\end{array}$ & $\begin{array}{c}\text { Approx. chi } \\
\text { square }\end{array}$ & 619.876 \\
\cline { 2 - 3 } & d.f & 406 \\
\cline { 2 - 3 } & Significance & .00 \\
\hline
\end{tabular}

The above table shows that KMO test has been applied to the resulting correlation matrix to test whether the relationship amongst the variables are significant or not . The test results shows that the significant value is approx.. 0.5 which is acceptable and therefore there is a significant relationship amongst the variables. The Bartlett test should be significant (i.e., a significance value of less than .05); here the Bartlett test value is .00 which signifies that the variables are correlated highly enough to provide a reasonable basis for factor analysis as in this case . 


\subsubsection{Component Matrix}

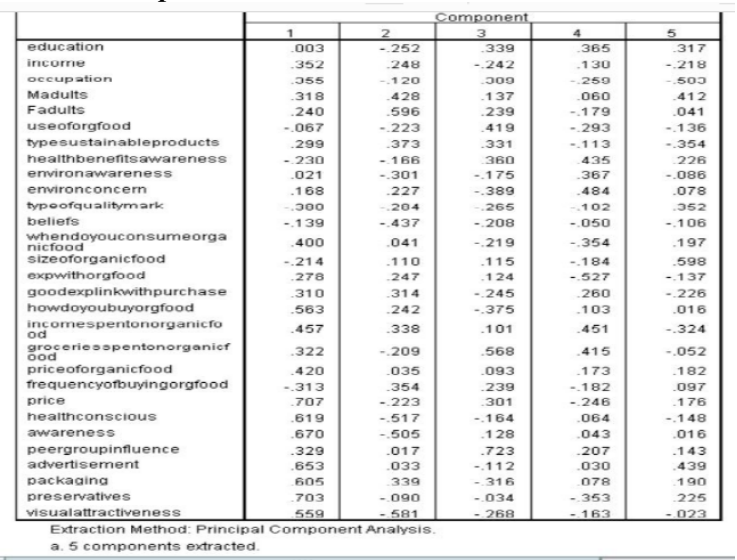

Fig. 28. Component matrix

\subsubsection{The rotated component matrix}

\begin{tabular}{|c|c|c|c|c|c|}
\hline \multicolumn{6}{|c|}{ Rotated Component Matrix } \\
\hline & & & emponen & & \\
\hline education & .052 & .067 & -.052 & -.163 & .614 \\
\hline income & 108 & 437 & .016 & 283 & -.157 \\
\hline occupation & .232 & -.285 & -.094 & .639 & .078 \\
\hline Madults & 265 & .292 & .531 & .055 & .189 \\
\hline Fadults & .102 & .122 & 632 & 273 & .068 \\
\hline useoforgfood & .047 &. .540 & .019 & .189 & .067 \\
\hline typesustainableproducts & .049 & .007 & .325 & .606 &. .035 \\
\hline healthbenefitsawareness &. .220 & .085 & -.030 & -.164 & .605 \\
\hline environawareness & .049 & 180 & -.443 & .039 & 177 \\
\hline emirancancerm & .060 & .671 & .070 & .083 & .070 \\
\hline typeofqualitymark & -.070 & -.160 & -169 & .601 & .095 \\
\hline beliefs & .009 & -.170 & -.454 & -.141 &. .113 \\
\hline $\begin{array}{l}\text { Whendoyouconsumeorga } \\
\text { nictood }\end{array}$ & 514 & 083 & 121 & .071 & -.288 \\
\hline $\begin{array}{l}\text { niciood } \\
\text { sizeoforganicfood }\end{array}$ & .062 & -.166 & .407 & -.507 & \\
\hline expwithorgfood & .288 & -178 & .342 & 310 & -349 \\
\hline goodexplinkwithnurchase & 008 & 532 & .004 & 286 & .092 \\
\hline nowdoyoubuyorgrood & .379 & .581 & .024 & .135 & -.167 \\
\hline $\begin{array}{l}\text { incomespentonorganicfo } \\
\text { od }\end{array}$ & .016 & .512 & .059 & .568 & .230 \\
\hline groceriesspentonorganicf & .151 & .051 & -079 & .364 & 693 \\
\hline priceoforganicfood & .341 & .228 & .085 & .080 & 260 \\
\hline frequencyofbuyingorgfood & -268 & -.184 & 461 & -.054 & -.046 \\
\hline price & .784 & -.154 & .079 & .226 & .189 \\
\hline nealthconscious & .586 & .104 & -.546 & 219 & .060 \\
\hline awareness & .683 & -.037 & -.354 & .223 & .283 \\
\hline peergroupinfuence & 230 & -.144 & .293 & 309 & .663 \\
\hline adverisement & 679 & 351 & .293 & $\begin{array}{r}.309 \\
-107\end{array}$ & .136 \\
\hline packaging & 455 & .603 & .196 & .054 & -.109 \\
\hline preservatives & 806 & .030 & 101 & .081 & -.108 \\
\hline visualattractiveness & 677 & .017 & & & -109 \\
\hline
\end{tabular}

Fig. 29 Rotated component matrix

\subsubsection{The total variance explained}

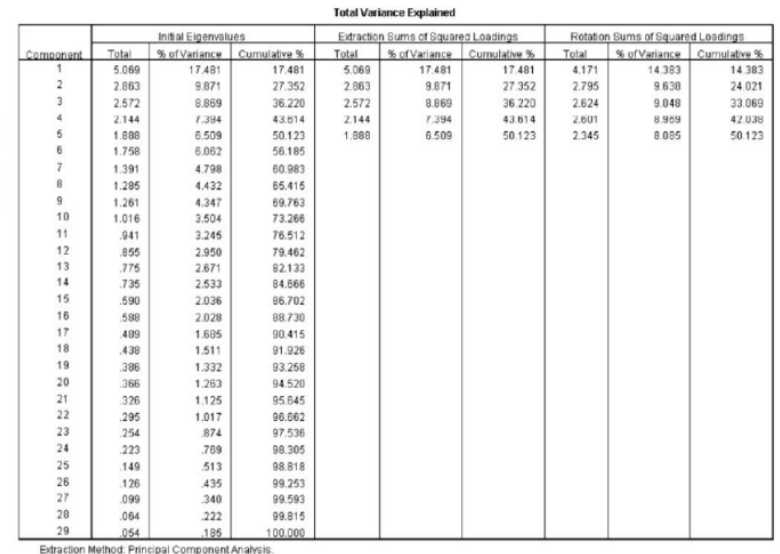

Fig. 30 The total variance explained

\subsubsection{Scree plot}

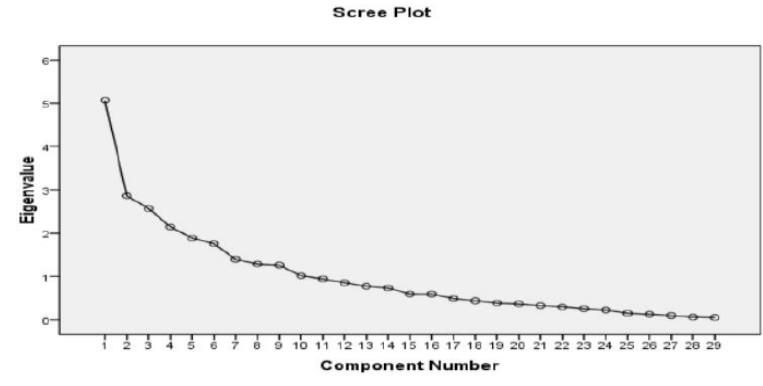

\section{MANAGERIAL IMPLICATIONS}

The present section deals with the managerial and IT related implications . For the detailed implications in other horizons such as logistics and / or infrastructure and management , authors may refer to [30]. They have been described in detail as follows :

1. Information technology and data analytics perspective Apart from Factor analysis , Bayesian analysis can be applied and data visualization can be performed with the bigger data set to study the consumer behaviour towards organic food products and testing of hypotheses can also be made .

\section{Conceptualization of consumer perception Bayesian network}

A Bayesian Network may be implemented in order to analyse the consumer perception about organic food products in developing countries like India through consumer perception and satisfaction survey data. The survey assessed the perception, belief and level of awareness and motivation towards the purchase of organic food products using several attributes. An important issue could be in consumer perception survey is to find which aspects of their perception, beliefs and purchasing behaviours influences their motivation and attitude to purchase . Bayesian Network is a useful tool to analyse such impact with the advantage that it produces graphical output that are easy to understand and make it simple to conduct

probabilistic inference for prediction.

Bayesian learning : In recent years, Bayesian network structure is a rapidly growing field of research. The initiation of classifiers from datasets of pre-classified cases is an important issue in Bayesian network learning. A most probable approach in the given scenario is the Greedy search constraint-based approach [31] . In general Greedy search approach is used to structure when the system is relatively unknown to us. Greedy search starts at a specific point in the structure space thereby considering all nearest neighbours of the existing point moving towards the neighbour with highest score . Algorithm eventually terminates when no neighbour appears with a higher score .

3. Higher research perspective : data mining and big data The research topic offers a plethora of possibilities for researchers. The study takes in to consideration just one category of sustainable food products i.e. organic food products. As mentioned in the questionnaire attached in the appendix, the concept can be extended to include biodegradable products, E-vehicle or even composts .

Apart from greedy search algorithm ( which is used to structure the data), meta heuristics and evolutionary algorithms may be applied in case of finding a compromised solution considering the optimization aspects of the modelling 
a discussion beyond the scope of present research work and serve as a excellent opportunity for researchers.

\section{CONCLUDING REMARKS}

Present study tries to explore and analyze interesting aspects related to consumer behavior, perceptions and attitudes about organic food products in Indian sub-continent . It also relates such consumption patterns with the consumers' understanding and points of view towards organic food as well as their demographic, socio-economic, purchasing patterns and consumption patterns profiles. Based on the conceptual framework which identify the required criteria that influences the consumer perceptions and attitude towards organic food products, data is collected from randomly selected organic food consumers through online as well as offline survey and using semi-structured questionnaire. A detailed data analysis is then performed applying factor analysis approach and results are presented. Further extension of the present research work could be a comparative analysis of Factor analysis and Bayesian analysis which is a working paper by corresponding author and beyond the scope of present research paper. However it may be discussed at length upon the readers' request.

\section{ACKNOWLEDGEMENTS}

Authors are thankful to Recventures Education Services Private Limited for funding and support for communicating this research .

\section{REFERENCES}

[1] Hosseinpour, M., Mohamed, Z., Rezai, G., Shamsudin, M. N. and Abdlatif, I. 2015. How Go Green Campaign Effects on Malaysia Intention towards Green Behaviour. Journal of Applied Sciences, 15(6), 929-933.

[2] Mc Eachern, M. and Mc Clean, P. 2002. Organic purchasing motivations and attitudes: Are they ethical? International Journal of Consumer Studies, 26, 85-92.

[3] Makatouni, A. 2002. What motivates consumers to buy organic food in the UK? British Food Journal, 104, 345352.

[4] Chen, M. F. 2007. Consumers attitudes and purchase intentions in relation to organic foods in Taiwan: Moderating effects of food-related personality traits. Food Quality and Preference,18, 1008-1021.

[5] Roitner-Schobesberger, B., Darnhofer, I., Somsook, S., \& Vogl, C. R. 2008. Consumer perception of organic foods in Bangkok, Thailand. Food Policy, 33, 112-121.

[6] Salleh, M. M., Ali, S. M., Harun, E. H., Jalil, M. A. and Shaharudin, M. R. 2010. Consumer's perception and purchase intentions towards organic food products: Exploring attitude among academicians. Canadian Social Science, 6(6), 119-129.

[7] Stolz, H., Stolze, M., Hamm, U., Janssen, M. and Ruto, E. 2010. Consumer attitudes towards organic versus conventional food with specific quality attributes. NJASWageningen Journal of Life Sciences, 58, 67-72.

[8] Grankvist, G. and Biel, A. 2001. The importance of beliefs and purchase criteria in the choice of eco-labeled food products. Journal of Environmental Psychology, 21, 405-410.

[9] Urban , J. , Zverinoya , I. and Scansy , M. 2012. What motivates Czech consumers to buy organic food ?, effects of label information on consumer willingness to pay for food attributes. Sociologický Časopis / Czech Sociological Review , 48(3), 509-536.

[10] Jan, V., Nguib, K. S. and Anand, A. 2011. Determinants of Willingness to Purchase Organic Food: An Exploratory Study Using Structural Equation Modeling, International Food and Agribusiness Management Review, 14(11).

[11] Ghorbani, M. and Hamraz, S. 2009. A study on factors affecting on consumer's potential willingness to pay for organic products in Iran (a case study). Trends in Agriculture Economics, 2, 10-16.

[12] Napolitano, F., Braghieri, A., Piasentier, E., Favotto, S., Naspetti, S., \& Zanoli, R. 2010. Effect of information about organic production on beef liking and consumer willingness to pay. Food Quality and Preference, 21, 207-212.

[13] Giovanni, P., Alessandro, M. P. and GianluigiI, G. 2012. Determinants of Regular and Occasional Consumers' Intentions to Buy Organic Food. Journal of consumer affairs, 157-169, Wiley.

[14] Briz, T., \& Ward, R. W. 2009. Consumer awareness of organic products in Spain: An application of multinomial logit models. Food Policy, 34, 295-304.

[15] Pieniak, Z., Aertsen, J. and Verbeke, W. 2010. Subjective and objective knowledge as determinants of organic vegetable consumption . Food Quality and Preference, 21, 581- 588.

[16] Marshall, D. W. and Bell, R . 2004. Relating the food involvement scale to demographic variables, food choice and other constructs. Food Quality and Preference, 15, 971-979.

[17] Mergenthaler, M., Weinberger, K. and Qaim, M. 2009. Consumer Valuation of Food Quality and Food Safety Attributes in Vietnam . Review of Agricultural Economics, 266- 283.

[18] Bartels, J. and Rienders, M. 2010. Social identification, social representations, and consumer innovativeness in an organic food context: A cross-national comparison. Food Quality and Preference, 21, 347-352.

[19] Ayswarya, R. And Vasanthi , S. 2018. Consumer Perception Towards Organic Products In Tiruchirappalli Corporation . Aripex - Indian Journal Of Research , 7(3), ISSN : 2250- 1991

[20] Leong, T.P. and Laily Paim, L. 2015. Factors affecting intention to consume organic food products: a study among Chinese college students in Malaysia. International Journal Review of Management and Business Research, 4 (1), ISSN: 2306-9007.

[21] Snyder, C. and Spaner, D. 2010. The Sustainability of Organic Grain Production on the Canadian Prairies. A Review, Sustainability, 2, 1016-1034.

[22] William, P. R. D. and Hammit, J. K. 2001. Perceived risks of conventional and organic produce: Pesticides, pathogens, and natural toxins . Risk Analysis, 21, 319330.

[23] Basha, M. B., Mason, C. and Shamsudin, M. F. 2015. Consumers Attitude Towards Organic Food. International Accounting and Business Conference, 31, 444-452. 
[24] Linder, N. S., Uhl, G., Fliessbach, K., Trautner, P., Elger, C. E. and Weber, B. 2010. Organic labeling influences food valuation and choice. Neuro Image, 53, 215-220.

[25] Sakagami, M., Sato, M. and Ueta, K. 2006. Measuring consumer preferences regarding organic labeling and the JAS label in particular. New Zealand Journal of Agricultural Research, 49, 247-254.

[26] Zhifeng, G. and Schroeder, T.C. 2009. Effects of label information on consumer willingness-to-pay for food attributes . American Journal of Agricultural Economics , 91, 795- 809 .

[27] Attanasio, S., Carelli, A. Cappelli, L. and Papetti, P. 2013. Organic food: A study on demographic characteristics and factors influencing purchase intentions among consumers in Pontina province. International journal of latest research in science and technology, 2(6). 128-132 . ISSN:2278-5299.

[28] Wee, C.S. , Ariff, S.B.M, Zakuan, N. and Naquib, M.M.T. 2014. Consumers perception, Purchase Intention and Actual Purchase Behavior of Organic Food and Products. Review of Integrative Business and Economics Research, 3(2) . ISSN:2304-1013

[29] Anisimova, T. 2016. Integrating multiple factors affecting consumer behaviour toward organic foods: The role of healthism, Hedonism and trust in consumer purchase intentions of organic foods. Journal of Food ProductsMarketingDOI:10.1080/10454446.2015.112142 9.

[30] Aggarwal , R. and Banerjee, R. 2018. A Conceptual Framework to measure customer experience towards organic food products in India", presented at ICSMS , IMT Nagpur and further communicated to Progress in Industrial Ecology , an International Journal , Inderscience, 2018.

[31] Heckerman, D. Geiger, D. , Chickering, D.M. 1995. Learning Bayesian networks: The combination of knowledge and statistical data, Machine Learning, 20, 197-243. 